\title{
Anthropogenic Impacts on Vegetation Diversity and Spatial Floral Composition of the Swamp Forest Associated With the Tropical River Basin
}

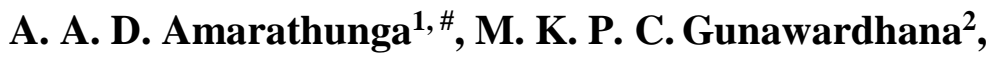 \\ H. M. G. S. B. Hitinayake ${ }^{2}$ and G. D. M. N. Jayawardana ${ }^{3}$ \\ ${ }^{1}$ Environmental Studies Division, \\ National Aquatic Resource Research and Development Agency, \\ Crow Island, Mattakkuliya, Colombo, Sri Lanka \\ ${ }^{2}$ Department of Crop Science, \\ Faculty of Agriculture, \\ University of Peradeniya, Peradeniya, Sri Lanka \\ ${ }^{3}$ Pitigala Ayurveda Hospital, \\ Edipalegoda, Pitigala, Galle, Sri Lanka \\ \#Corresponding Author: \\ Tel: (+94) 11252 1009; Email: deeptha@nara.ac.lk
}

\begin{abstract}
The Gin river wetland marsh has been identified as one of the most dynamic ecosystem in Sri Lanka, providing habitats for associated floral and faunal communities under a permanent or temporary accumulation of water. Study was focused to understand the structure, composition and threats of the Ginthota wetland marsh, by identifying the biodiversity distribution, anthropogenic activities and evaluation of water quality changes. Vegetation was sampled in randomized plots and water samples were collected in the three sampling locations. Fifty seven species of plants of twenty three different families were identified. Out of them, forty eight species were native and five were introduced. Argyreia populifolia was identified as an endemic species. Three plants were identified as dominant plant species Sonneratia caseolaris, Annona glabra and Acrosricum auriyam. Annona glabra was an invasive species and Nypa fruticans was an endangered species. The Shannon-Wener Index for the disturbed and undisturbed areas was 0.685 and 1.721 respectively, reflecting a higher biodiversity in the undisturbed areas. Many anthropogenic factors are causes for the deteriorating diversity and also water quality.
\end{abstract}

KEYWORDS: Anthropogenic impact, Diversity, Flora, Gin river, Wetland marsh 


\section{Introduction}

Rapid increases of extinction of species because of habitat destruction, agricultural transformation, the dominance of alien invasive species, and extraction for medicinal purpose or over harvesting for domestic purpose have heightened importance of biodiversity studies in wetlands (Kerr and Ostrovsky, 2003; Kerr and Deguise, 2004; Hastings et al., 2005; Sinclair and Byrom, 2006). Recently, reported that 844 of species were extinct from the world because of various reasons and 29 $\%$ are threatened species. In addition, $34 \%$ of gymnosperms are globally threatened (IUCN, 2004).

For thousands of years wetlands have provided mankind with an almost inexhaustible source of food, building and utility materials. Today also wetlands are containing a large part of the world's as a biological heritage (Goldewijk, 2004; Hermoso et al., 2012; Rooney et al., 2013). Wetlands have been identified as a most dynamic ecosystem among other natural ecosystems. It provides habitats for the associated floral and faunal communities by permanent or temporary accumulation of water (William and Gosselink, 1986; Gibbs, 1993; Gibbs, 2000). Wetlands are categorized into different types based on basically whether it holds fresh, brackish or salt water, whether the water is stagnant or flowing, or whether it has a permanent or seasonal character (Bornette et al., 2008; Więski et al., 2010). Swamp wetlands dominated by trees or shrubs and frequently or continually inundated wetlands characterized by emergent herbaceous vegetation to saturated soil conditions is called as marsh (William and Gosselink, 1986).

Wetlands are also important in conservation of gene pools of wild varieties of crop, fish, amphibian and endemic tree species (Siwakoti and Tiwari, 2007). Wetland vegetation influences hydrological conditions by trapping and binding sediments to reduce erosion, by interrupting water flows, and by building peat deposits (Gosselink, 1984). In the past, wetlands were considered as wastelands that could be reclaimed or changed for use by mankind. Development initiatives have regarded these areas suited only for such purposes, and as a consequence, many wetlands have been drained or used as dump sites for refuse and urban waste (CEA and IUCN, 2006).

Sri Lanka has an extensive network of rivers and streams that drains a total of 103 distinct natural river basins and there are 28 river basin area are exceeding $500 \mathrm{~km}^{2}$. The most of river basins are perennial (Arumugam, 1969; De Silva, 1988). Therefore, a country rich with freshwater wetlands and these wetlands is vested under the Fauna and Flora Protection Ordinance of 1938 and its amendments with the wildlife sector (Gazzate, 1938). However, for a number of reasons, due recognition for the importance of conserving wetlands in the country has not effectively come off the ground until recently (CEA and IUCN, 2006). Many wetlands are being encroached by industrial facilities, roads, development projects and settlements which led to threatening of biodiversity and wetland functions (Amarathunga and Hitinayake, 2012; CEA and IUCN, 2006). 
Gin River associated wetlands still not studied well and its diversity with complex and functions are still unknown. Recently, many reported suggests that higher suspended sediment and nutrient flowing from upper catchment to downstream because of anthropogenic activities (Amarathunga et al., 2013a ; Amarathunga et al., 2013b) and wetland are important for pollutant trapping (Rogers et al., 2009; Amarathunga and Hitinayake, 2012). Therefore, the study was conducted to understand the structure with the composition of flora in wetland and main anthropogenic activities threats to flora. In addition, the study was focused to natural impacts threatening to the biodiversity of wetlands including water quality changes.

\section{Methodology}

\section{Study Area}

Gin River (Gin Ganga) which starts from Gongala mountain region with Sinharaja forest and end at sea at Ginthota. Gin Ganga associated wetland is located in the southern lowland belonging to Gintota and Hikkaduwa secretariat divisions in Galle district and nourishing by Gin river which experiences a hot tropical climate (Arumugam, 1969; Survey Department, 1988; Bandara, 1990). The mean annual temperature remains around $28^{\circ} \mathrm{C}-31^{\circ} \mathrm{C}$ throughout the year, prolong two main monsoons from the Indian Ocean affecting the rainfall and humidity (Survey Department, 1988).

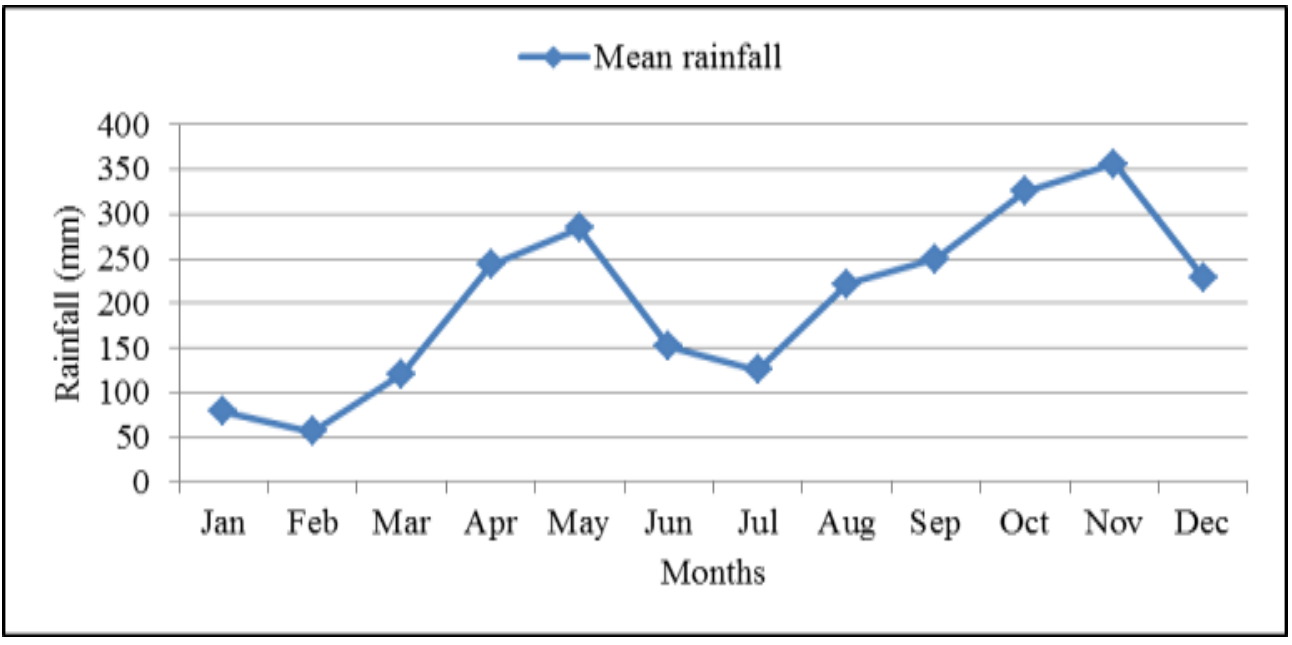

Figure 1. Mean rainfall variation in the 5 years period (2010-2014) around the associated wetland marsh in Gin river Basin

Average rainfall is about $25000 \mathrm{~mm}$. The south - west monsoon affects the area from May to September, with rainfall levels increasing from March to April, when as much as 300mm or above can fall during this period (Survey Department, 1988). 
Figure 1 illustrates rainfall variation near wetland and it shows high rainfall from two monsoon periods. The natural vegetation of the study area was characterized by mangroves and other wetland plants and because of nearness to the sea, salt water impact also influence to the biodiversity of wetland marsh (Figure 2). The area was consisting with Red-yellow podzolic soil with alluvial of variable drainage and texture in the area (Mapa et al., 1999). The landform of the area is undulating and deep weathering of rocks, as observed in embankments and cuttings, have resulted in the development of low ferruginous clays and sand that have been washed down during erosion and have collected in the areas such as marsh lands. Theses soil exhibit poor drainage capacities that could inhibit normal root growth in plant species.

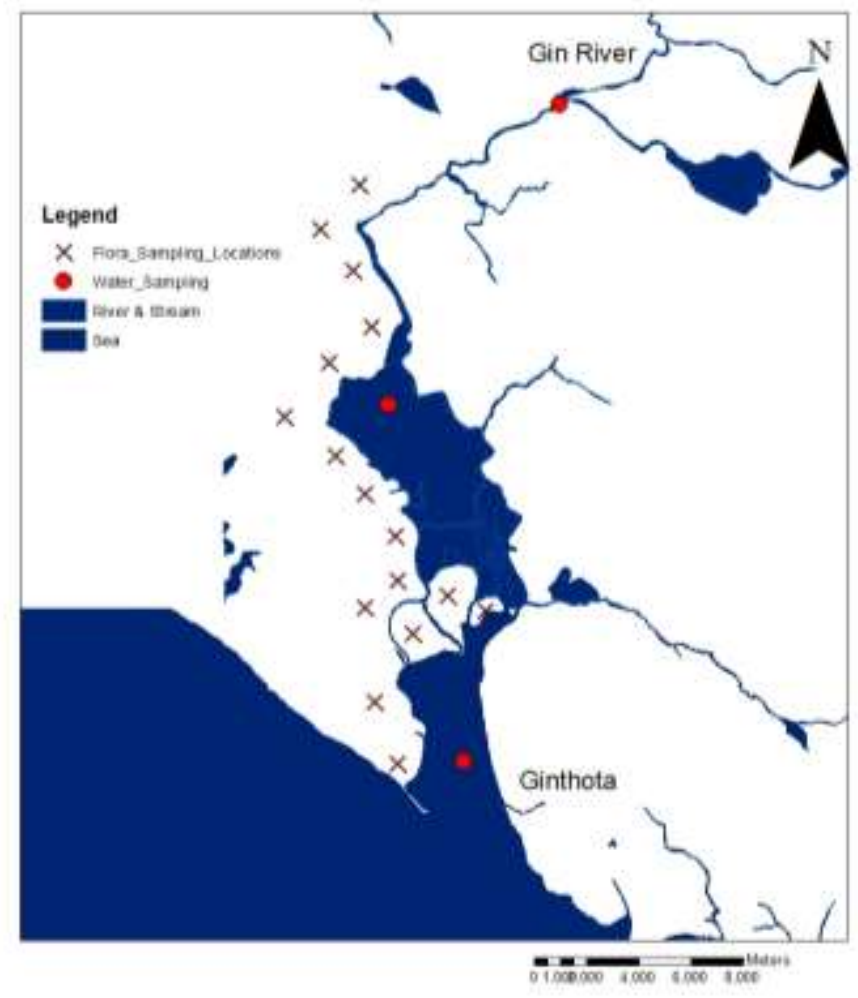

Figure 2. Sampling locations of the study area

\section{Sample Collection and Identification}

\section{Flora}

Field surveys were carried out to identify the plant species. Flora of the wetland islet were sampled using $10 \mathrm{~m} \times 10 \mathrm{~m}$ quadrate sampling plots (ST) laid at different locations (15) based on the random sampling techniques (Kaiser, 1983; Zeleny and Chytry, 2007). Two belt transact visits were carried out to discover wetland flora 
other than quadrat sampling; one transact visit was done through inland forest were and the other was done within the seasonally flood wetland area. Also, unidentified specimens from wetlands were collected. The results were used to discover the dominant plant species, invasive species, native species, introduced species, endangered species, diversity and comparisons with other wetland ecosystems. Plant species were identified using Flora of Ceylon (1980-1987), Handbook to the flora of Ceylon (Trimen, 1893) common trees and shrubs in Sri Lanka (Ashton et al., 1997) and a checklist of flowering plant of Sri Lanka (Senaratna, 2001). The specimens that could not be identified in the field were tagged. Those specimens were sent to compare with herbarium specimens at the Royal Botanical Garden in Peradeniya. When the species density was very high (more than 50), randomized $1 \mathrm{~m} \times 1 \mathrm{~m}$ sub-plots were adopted and recounted. The median values of each plot were obtained and calculations were done to get the actual figure.

\section{Water Sampling and Analysis}

Three sampling locations were selected according to random sampling techniques to get water samples considering upper part, inside wetland and after passing the wetland (Figure 2). Subsurface water samples were collected from middle at $50 \mathrm{~cm}$ to $100 \mathrm{~cm}$ depth in the stream and in-situ analysis was done in water temperature, $\mathrm{pH}$, dissolved oxygen (DO), electrical conductivity (EC), turbidity, suspended sediment and salinity. Additionally, samples were tested for nutrient parameters, such as nitrate nitrogen, nitrite nitrogen, ammonia nitrogen and dissolve phosphorus (APHA, 1998).

\section{Secondary Data Collection}

Participatory Rural Appraisals (PRA) and discussions were made to gather information from adjacent people in the wetland marsh. Knowledgeable local people who are distributed in that area were consulted. Thereafter preliminary field study was carried out to identify habitants and distribution of plant species in the wetland. Secondary Data were collected from Gintota and Hikkaduwa Secretariat Divisions in Galle District.

\section{Statistical Analysis}

Biodiversity statistical software (biodiversity pro) used for statistical analysis. Shannon - Wener Diversity Index was used to characterize species diversity in the eco-community and its account for both abundance and evenness of the species present. The proportion of species (i) relative to the total number of species $(\mathrm{A}=$ $\left.\pi r^{2}\right)$ is calculated, and then multiplied by the natural logarithm of this proportion (Ln pi). The resulting product is summed across species, and multiplied by (-1):

$$
H=-\sum_{\mathrm{i}=1}^{5} p_{\mathrm{i}} \ln p_{\mathrm{i}}
$$


In addition, species richness (S), total abundance and evenness were calculated. Cluster analysis was done using SPSS statistical software. Standard deviation and the mean values were calculated for each of the above parameters calculated from samples taken from both disturbed and undisturbed areas. Also, mean and standard deviation of water quality parameters calculated using SPSS statistical software.

\section{Results and Discussion}

\section{Landscape and Physical Features}

Basically, Gin river associated wetland in Ginthota is categorized into the intertidal forested wetland. There are river streams and marshy lands. It has many isolated wetland islets with islands. Some of the islets interconnected with small strips of scrub wetland forests. Mangrove mixed swamps and scrub forest extents were relatively higher in the wetland. In addition to that, a very small area of inland forest coverage is present. The wetland covered approximately 15 hectares, out of which, approximately 10 hectares are marshy lands. Approximately 2 hectares come under the coastal line, whilst the widely spread patches of mangroves cover about a hectare. Apart from that, 2 hectares of the observed land area gets flooded seasonally or permanently. The rest of the solid ground is under woody bushes.

\section{Vegetation Types and Floral Diversity in the Wetland}

The study area is consisting with different habitats; undisturbed forest lands, abandoned agricultural lands, and agriculture areas with various biodiversity levels. Fifty seven species of plants of twenty three different families were identified under quadratic sampling and transact visit in the study areas. One endemic species were identified in this area and among them, forty eight were native and six species were introduced. Three dominant plant species were identified from the entire ecosystem; i.e. Sonneratia caseolaris, Annona glabra and Acrosricum auriyam. The total plant species were listed in Annex 1.

Major differences of higher undergrowth in the inland forest areas and seasonally flood swamp forest were noted during the transact visit. Inland forest patches consist on three distinct vegetation strata characterized in this habitat. The upper most tree layer (canopy layer) is composed of species such as Sonneratia caseolaris, syzygium caryophyllatum, Ficus racemosa and Acacia mangium. Within the sub canopy layer, Pandanus odoratissimus, Cerbera manghas, Bruguiera gymnorrhiza and Annona glabra. Below the sub canopy layer, shrubby plants such as Melastomamala bathricum, Hanguana malayana, Hydrocera triflora and Ziziphus spp. The Forest floor consists of the plants Cyprus spp. It is also noted that, vegetation of many scrubland sites was modified due to the invasion of Merremia hedaracea and Mikania scandens. 
Seasonally flooded swamp forest is consisting with three major vegetation layers. The top most layer was canopy layer; It's contains Sonneratia caseolaris, Acacia mangium and Ficus racemosa. Within a sub canopy layer, trees consist with Bruguiera gymnorrhiza, Symplocosco chinchinensis, and Nypa Fruticans and shrub consist, such as, Symplocoscochin chinensis, Ixora hybrids, and Pandanusodora tissimus. The Forest floor consists of very rare plant species, because this area was seasonally flooded forest are rare. In addition, Barringtonia racemosa, Acrostichum aureum, and Hanguana malayana were identified between the inland forests patch and swamp forest area.

The dominant mangrove species occurring in swamp forest habitats were Sonneratia caseolaris. Also, the major mangrove species found there were, Nypa fruticans, Bruguiera gymnorrhiza, and Sonneratia caseolaris. Of these four mangrove species, Kirala and Mal Kadol were categorize as very common, true mangrove plant species in Sri Lanka (Silva and Silva, 1998).

Gin Pol was categorized as common and endangered mangrove plant species (MOE, 2012). Abandon agricultural lands, mostly covered by introducing plant species such as; Alocasia macrorrhizos and an invasive alien species Annona glabra were recorded at the site. This has been identified as a threatening, invasive species in some other Sri Lankan habitats as well (Bambaradeniya, 2001). In addition, Merremia hederacea and Mikania scandens are covering the entire open lands.

The computed Shannon-Wener diversity index was 1.24 , which was calculated by selecting fifteen plots randomly, on behalf of the whole ecology of the wetland marsh. However, the eight plots were laid in the undisturbed land and the computed diversity index was 1.72 which is greater than the calculated diversity index (1.24) for the whole wetland marsh. In addition, seven plots were laid in the disturbed land areas and computed diversity index was 0.68 , which is lower than the calculated diversity index (1.24) for the whole wetland marsh.

The lowest values of the diversity index from agriculture land and it was highly impacted entire disturb area diversity index. According to the Shannon-Wener Diversity Index of disturbed areas, the plot ST-4 was gaining very minute value compared to ST-3, which was gaining the highest value. Table 1 shows a clear variation of diversity index difference between disturbed and undisturbed areas. Using the above mean values the percentage reduction in biodiversity in both disturbed and undisturbed areas was estimated. 
Table 1. The biodiversity indices of the sample

\begin{tabular}{|c|c|c|c|c|c|}
\hline Category & Plot No & $\begin{array}{l}\text { Shannon-Wener } \\
\text { Diversity Index }\end{array}$ & $\begin{array}{c}\text { Species } \\
\text { Richness } \\
\text { (S) }\end{array}$ & $\begin{array}{c}\text { Total } \\
\text { Abundance }\end{array}$ & Evenness \\
\hline \multirow{7}{*}{ 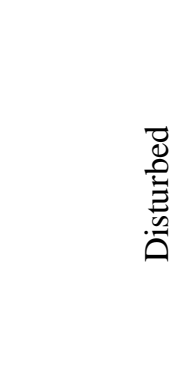 } & ST-2 & 0.282 & 13 & 86481 & 0.11 \\
\hline & ST-4 & 0.008 & 6 & 40031 & 0.004 \\
\hline & ST-7 & 0.847 & 4 & 38 & 0.611 \\
\hline & ST-8 & 1.3 & 5 & 140 & 0.808 \\
\hline & ST-9 & 1.166 & 7 & 162 & 0.599 \\
\hline & ST-12 & 1.099 & 3 & 30 & 1.0 \\
\hline & ST-13 & 0.092 & 4 & 6106 & 0.066 \\
\hline \multirow{8}{*}{ 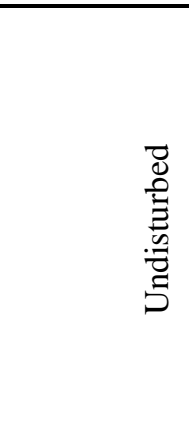 } & ST-1 & 1.722 & 6 & 104 & 0.961 \\
\hline & ST-3 & 2.337 & 16 & 135 & 0.843 \\
\hline & ST-5 & 1.334 & 4 & 14 & 0.962 \\
\hline & ST-6 & 1.198 & 5 & 51 & 0.744 \\
\hline & ST-10 & 1.942 & 10 & 108 & 0.843 \\
\hline & ST-11 & 1.782 & 12 & 173 & 0.717 \\
\hline & ST-14 & 1.739 & 9 & 138 & 0.791 \\
\hline & ST-15 & 1.718 & 7 & 56 & 0.883 \\
\hline
\end{tabular}

It was found that there is a $60.3 \%$ reduction of biodiversity in the disturbed area. This is more than $50 \%$ reduction. It is reduced at an alarming rate. If this continues further it will reach a level where the biodiversity cannot be recovered. The species richness was computed, 7.4 recorded as for the entire ecosystem. However, undisturbed area was recorded 8.63 which are higher than the entire ecosystem. Also, 6.0 species richness was recorded in disturb area.

Table 1 illustrated a clear variation of species richness between disturbed and undisturbed areas. The highest species richness belongs to plot number ST-3 and the lowest value belongs to ST-12. But some plots in the undisturbed areas also contain very low values of species richness. They are (ST-1, ST-5, and ST-6). Because these three plots were situated in the permanent flooding areas of the study area. In addition, computed total abundance for entire ecosystem is given in Table 2, based on the 15 quadratic sampling. The computed total abundance from disturb area was around 8917 and from the undisturbed area is 18998. 


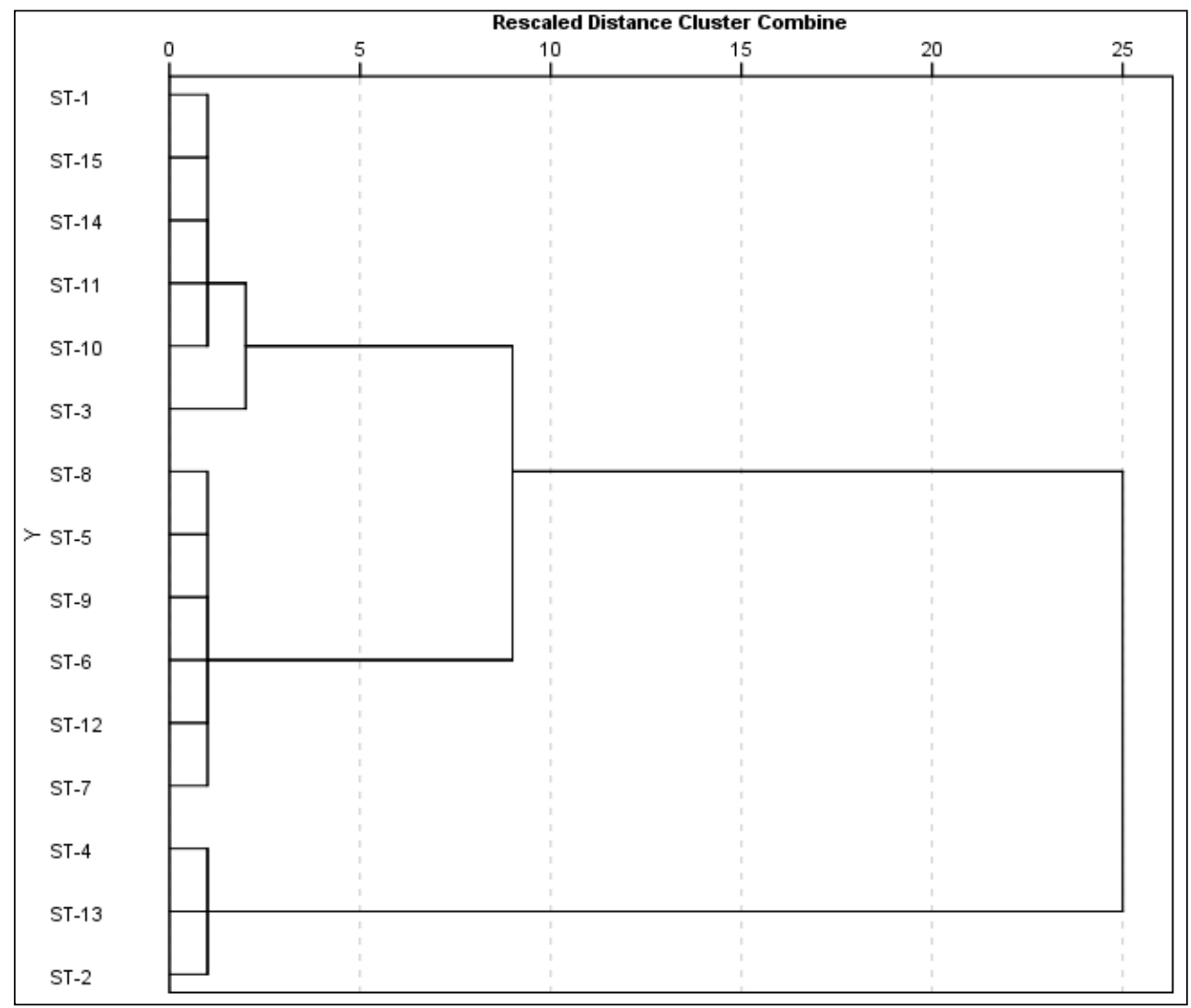

Figure 3. Results of the cluster analysis for Shannon-Wener Diversity Index

Based on the study, forty eight species were identified as native species, six species were introduced and Argyreia populifolia (Girithilla) was endemic to the study area. Also, every index showed a clear variation between the disturbed and undisturbed areas (Table 1). Pooled $t$ test was carried out for the collected data. It revealed that there were significant differences between species richness and Shannon-Wener Diversity Index of undisturbed and disturbed area.

Statistical analysis showed, major two clusters, low diversity index and high diversity index which is illustrated in Figure 3. ST-2, ST-13 and ST4 belong to low Shannon-Wener diversity Index cluster. High diversity cluster again separates to another two clusters and ST-1, ST-3, ST-10, ST-11, ST-14 and ST-15 belong to highest Shannon-Wener Diversity Index which belongs to undisturbed area. Results reveal that medium level Shannon-Wener Diversity also presents in disturb area of the forest. The summary of the biodiversity indices of the study area illustrated in the Table 2. 
Table 2. The biodiversity indices of the study area

\begin{tabular}{cc}
\hline Index & Value \\
\hline Total abundance & 8917.8 \\
Shannon-Wener Diversity Index & 1.2376 \\
Species richness & 7.4 \\
Evenness & 0.6629 \\
\hline
\end{tabular}

\section{Water Quality Impact}

Gin Ganga basin mainly experiences southwest monsoon rain from May to September and floods are usually experienced during south-west monsoon and second inter monsoon (October - November). Significant amount of suspended sediment was brought through the river from the upper and middle catchment during the rainey period (Figure 4).

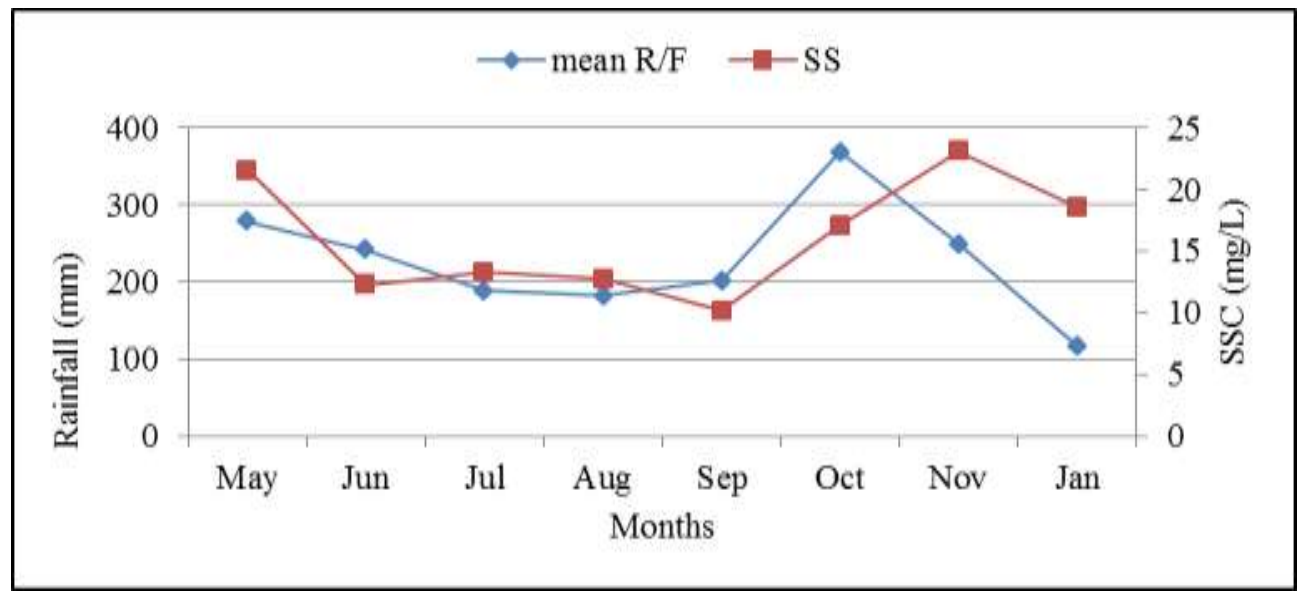

\section{Figure 4. Relationship between rainfall and suspended sediment concentration in downstream}

The water quality of the three sampling locations (before wetland, inside wetland and after passing the wetland) is illustrated in Table 3. These results indicate that there are no significant differences in $\mathrm{pH}$ in wetland marsh and reference point. There was a significant difference in the water temperature in the wetland and other sampling locations (Table 3). The many factors influencing to water temperature in the stream such as, seasonality, daily time scales, locations due to climate, elevation and streamside vegetation (Allan, 1995). The study revealed that the lower levels of temperatures were recorded where the samples collected in forest areas (inland and swamp forest) and there were no significant seasonal water temperature variation in the sub-catchment $(26.0 \pm 1.0)$, because the seasonal changes in water temperature closely follow seasonal trends in mean monthly air temperature (Allan, 1995). Thus, the measured air temperature was varied between $29.5^{\circ} \mathrm{C}$ to $33.0^{\circ} \mathrm{C}$ in the wetland area during the study period. 
Table 3. Average, minimum, maximum and standard deviation of parameters tested in water samples

\begin{tabular}{cccc}
\hline Parameters & Before & $\begin{array}{c}\text { Inside the } \\
\text { Wetland }\end{array}$ & After wetland \\
\hline Water Temperature $\left({ }^{\circ} \mathrm{C}\right)$ & $27.7 \pm 1.6$ & $26.0 \pm 1.0$ & $29.0 \pm 1.4$ \\
& $(25.1-29.7)$ & $(24.5-27.8)$ & $(26.8-32.3)$ \\
$\mathrm{pH}$ & $5.95 \pm 0.2$ & $6.12 \pm 0.3$ & $6.19 \pm 0.5$ \\
& $(5.45-6.34)$ & $(5.64-6.84)$ & $(5.55-7.31)$ \\
DO (mg/L) & $5.9 \pm 1.2$ & $5.57 \pm 1.0$ & $6.03 \pm 1.3$ \\
& $(4.4-7.3)$ & $(4.0-6.8)$ & $(4.3-8.8)$ \\
EC $(\mu \mathrm{S})$ & $33.76 \pm 9.1$ & $384.03 \pm 1071.5$ & $981.37 \pm 2079.6$ \\
& $(25.3-58.3)$ & $(28.5-3910)$ & $(31.8-7460)$ \\
Turbidity $(\mathrm{NTU})$ & $35.92 \pm 43.45$ & $27.15 \pm 23.88$ & $21.90 \pm 21.1$ \\
& $(6.33-159.9)$ & $(6.11-75.1)$ & $(5.83-74.6)$ \\
Ammonia nitrogen & $0.20 \pm 0.38$ & $0.23 \pm 0.36$ & $0.23 \pm 0.32$ \\
$(\mathrm{mg} / \mathrm{L})$ & $(0.01-1.46)$ & $(0.04-1.42)$ & $(.06-1.26)$ \\
& $0.01 \pm 0.004$ & $0.01 \pm 0.002$ & $0.01 \pm 0.003$ \\
Nitrite nitrogen $(\mathrm{mg} / \mathrm{L})$ & $(0-0.02)$ & $(0-0.01)$ & $(0-0.01)$ \\
& $2.63 \pm 1.4$ & $2.57 \pm 1.4$ & $1.98 \pm 0.9$ \\
Nitrate nitrogen $(\mathrm{mg} / \mathrm{L})$ & $(0.52-4.62)$ & $(0.49-4.91)$ & $(0.49-3.77)$ \\
Dissolve phosphate & $0.78 \pm 1.2$ & $0.67 \pm 1.0$ & $0.46 \pm 0.4$ \\
$(\mathrm{mg} / \mathrm{L})$ & $(0.05-4.45$ & $(0.04-3.42)$ & $(0.04-1.15$ \\
Suspended sediment & $38.93 \pm 17.5$ & $33.32 \pm 14.2$ & $25.43 \pm 12.8$ \\
concentration $(\mathrm{mg} / \mathrm{L})$ & $(9.6-60.9)$ & $(9.1-51.6)$ & $(9.1-51.6)$ \\
\hline
\end{tabular}

Saturation of dissolved oxygen concentrations was occasionally observed in the wetland and low level of dissolved oxygen concentrations was observed in the wetland when compared with other two sampling locations. Nitrogen and phosphorus were the major factors responsible for the productivity of a water body and also indicative of the anthropogenic activities (Frumin and Gildeeva, 2014). Ammonia nitrogen, nitrite nitrogen, nitrate nitrogen and dissolve phosphate concentrations, these four parameters were behaving more or less similar and a reduction in concentrations was observed from the wetland marsh and after passing of it. Significant differences of turbidity values were observed three sampling locations and reveal that, after passing the wetland turbidity decreases.

Amarathunga (2014) reported that, high amount of suspended sediment concentrations was recorded in the middle and lower catchments of Gin River basin and also, results reveal that, before wetland suspended sediment concentrations was higher than in wetland and after wetland sampling locations (Table 3). Rogers et al., 2009; Shadrack et al., 2015 are reported that wetland are acting as a sediment trap 
based on their flow. Therefore, it can assume that, Gin river associated wetland with downstream is retained suspended sediment.

\section{Threats to Biodiversity}

According to the observations made during the survey, several anthropogenic activities were posing a threat to the biodiversity associated with the Wetland marsh in the Gin Ganga. The major threats that affected the biodiversity can be summarized as: agriculture activities, direct exploitation of species and deforestation, unregulated animal husbandry activities, spread of invasive alien species and development activities.

\section{Agriculture Activities}

Agricultural activities had mainly concentrated near rivers, because river floodplains were exceptionally fertile due to many nutrients that were deposited in the soil when the river overflew. Also less pest and disease problems occurred, as the river acted as a geological barrier. River provided free transport for their products. However, the clearing of the forest land is the most destructive action on the wetland for agriculture purposes. They remove valuable plant species, including mangroves. It causes many environmental impacts to the area; biodiversity loss, bund erosion and endanger the natural habitats of the plant and animal species.

\section{Direct Exploitation of Species and Deforestation}

Village communities harvest plant species as medicinal plants, as an ornament or their day to day activities. This was not done in a sustainable manner. However, mangrove trees and other tree species were cut in an unsustainable manner of different household uses. Also the trees were used as fire for the distillery process in illegal liquor preparation and the ultimate result is deforestation.

\section{Spread of Alien Invasive Species}

Annona glabra was found to be an invasive species growing in this ecosystem. It was recorded in 10 plots out of the 15 considered for the study. This has already been recorded as an invasive species in other areas of the country (Amarathunga and Hitinayake, 2012).

\section{Unregulated Animal Husbandry Activities}

The grasslands of the Ginthota area are overgrazed by cattle and buffalo roaming freely. Several grasslands had been eroded due to overgrazing. These animals had also facilitated the spread of invasive alien plants. Buffalos used to wallow in muddy conditions causing most of the land areas to become unsuitable for plant ecosystems. Human interference in these ecosystems also became higher due to 
animal husbandry. A commercial cultivation of prawns was on the way to be established in this area which can be an immense disaster to the ecosystem.

\section{Development Activities}

Encroachment of the ecosystem for building of houses was a common practice near the boundaries of the wetland. The people of the area intruded the natural ecosystem to expand their lands. The present study has clearly revealed that the wetland area harbours a rich biodiversity, including a wide variety of ecosystems, habitats and species. The area served as a refuge for several endemic as well as threatened species of plants. Tourism is the potential threat in the future to this wetland because of land-use and development activities. Three major sources of pollution (industry, agriculture and domestic) were concentrated along the wetland. As in this cause industries and cities had been located along rivers because the rivers provide transportation and convenient place to discharge waste.

\section{Conclusions}

The Gin river associated wetland is important ecosystem and fifty seven plant species belong in to twenty three families were recorded. One highly endangered species Nypa fruiticans and one endemic species Argyreia populifolia (Girithilla) were observed. Forty eight native species and five introduced species were also found. In addition, results clearly illustrate that, there is a significant diversity, difference in the vegetation between disturbed and undisturbed areas of the site. The undisturbed area is rich in biodiversity. However, the biodiversity in the disturbed area is at a very alarming position. It is in a state where it's difficult easy to recover. Water quality parameters are under normal conditions except turbidity and results reveal that, turbidity is higher inside wetland than outside. It was found that the wetland buffers nutrient and suspended sediment from the river water based on the river flow. People in the vicinity do not use the area sustains. They are over exploiting of resources. People who live in the closer proximities to wetland highly benefited from this forest. Also, agriculture and development activities are an eminent threat to biodiversity of wetland and changes of the composition and structure of the marsh land will ultimately affect the function, the value and the utilization of the wetland. Hence, it can be concluded that Gin river associated wetlands are every important for both biodiversity conservation and management and meeting socioeconomic needs of the local community.

\section{Acknowledgements}

The authors would like to express their gratitude to National Aquatic Resources Research \& Development Agency (NARA) for financial support. 


\section{References}

Allan, J. D. (1995). Stream Ecology. "Structure and function of running waters". Clawer Academic Publishers, Netherlands.

Amarathunga, A. A. D. and H. M. G. S. B. Hitinayake (2012). "Vegetation structure and faunal composition of Wathurana wetland ecosystem in Tebuwana, Kalutara, Sri Lanka”. Journal of the National Aquatic Resource Research \& Development Agency, 41: 59-78.

Amarathunga, A. A. D., S. U. P. Jinadasa and S. A. M. Azmy (2013a). "Sedimentary characteristics and status of water quality in Polwatta river, and Weligama bay in Sri Lanka". Journal of Environmental Professionals Sri Lanka, 2(1): 38-51.

Amarathunga, A. A. D., K. A. W. S. Weerasekara, N. Sureshkumar, S. A. M. Azmy, W. D. N. Wickramaarchchi and F. Kazama (2013b). "Behavior and loading of suspended sediment and nutrients from river basins in the hilly catena under intensive agriculture cropping: a case study in Upper Kotmale basin in Sri Lanka”. Journal of Environmental Professionals Sri Lanka, 2(2): 13-31.

Amarathunga, A. A. D. (2014). "Behaviour of pesticide in tropical river basin with high concentrated suspended sediment".

Arumugam, S. (1969). "Water Resources of Ceylon”. Water resources board, Colombo, Sri Lanka.

Ashton, S. M., S. Gunathilake, N. D. zoysa, M. D. Dassanayake, N. Gunathilake and S. Wijesundera (1997). "A field guide to the common trees and shrubs of Sri Lanka". Wildlife Heritage Trust Found.

Bambaradeniya, C. N. B. (2001). "The Fauna of Sri Lanka; status of taxonomy, research \& conservation". The World Conservation Union, Colombo, Sri Lanka. pp.114.

Bandara, C. M. M. (1990). "Land resources and water resources". Natural resources of Sri Lanka. National Science foundation, Colombo, pp53-109.

Bornette, G., E.Tabacchi, C. Hupp, S. Puijalon and C. J. Rostan (2008). “A model of plant strategies in fluvial hydrosystems”. Freshwater Biology, 53: 1695-1705.

Central Environment Authority (CEA) and International Union for Conservation of Nature IUCN (2006). National Wetland Directory Sri Lanka, Colombo, Sri Lanka.

De Silva, S.S., (1988). “Reservoirs of Sri Lanka and their fisheries”. FAO Fish.

Frumin, G. T. and I. M. Gildeeva, (2014). "Eutrophication of water bodies - A global environmental problem", Russian Journal of General Chemistry, 84(13): 2483-2488.

Gazzate (1938). "Flora and fauna protection ordinance of Sri Lanka". Available online: http://www.commonlii.org/lk/legis/consol_act/fafp567290.pdf (Accessed: 09 September 2014). 
Gibbs, J. P. (1993). "Importance of small wetlands for the persistence of local populations of wetland-associated animals". Wetlands, 13: 25-31.

Gibbs, J. P. (2000). "Wetland loss and biodiversity conservation”, Conservation Biology, 14 (1): 314-317.

Goldewijk, K. K. (2004). "Footprints from the past: blueprint for the future?", Houghton (Ed.). Ecosystems and Land Use Change, Geophysical Monograph Series 153, American Geophysical Union, pp 203-215.

Gosselink, J. G. (1984). The ecology of delta marshes of coastal Louisianana: a community profile. U.S. Department of Interior Fish and Wildlife Service Circular 39. Washington, D.C, pp 143.

Hermoso, V., D. P. Ward and M. J. Kennard (2012). "Using water residency time to enhance spatio-temporal connectivity for conservation planning in seasonally dynamic freshwater ecosystems", Journal of Applied Ecology, 49: 1028-1035.

Kaiser, L. (1983). "Unbiased estimation in line-interception sampling”, Biometrics, 39: 965976.

Kerr, J. T. and I. Deguise (2004). "Habitat loss and the limits to endangered species recovery", Ecology Letters, 7: $1163-1169$.

Kerr, J. T. and M. Ostrovsky (2003). "From space to species: ecological applications for remote sensing”, TREE, 18: 299-305.

Mapa, R. B., S. Somasiri and S. Nagarajah (1999). "Soils of the wet zone of Sri Lanka: morphology, characterization, and classification”, Soil Science Society, Sri Lanka.

Ministry of Education (MOE) and the National Red List of Sri Lanka (2012). "Conservation status of the fauna and flora”, Ministry of Environment, Colombo, Sri Lanka, pp 476.

Rogers, J. S., K. W. Potter, A. R. Hoffman, J. A. Hoopes, C. H. Wu, and D. E. Armstrong, (2009). "Hydrologic and water quality functions of a disturbed wetland in an agricultural setting", Journal of the American Water Resources Association, 45(3): 628-640.

Rooney, R. C., C. Carli and S. E. Bayley (2013). "River Connectivity Affects Submerged and Floating Aquatic Vegetation in Floodplain Wetlands", Wetlands, 33: 1165-1177.

Senaratna, L. K. (2001). "Check list of flowering plants of Sri Lanka", National Science Foundation, Sri Lanka.

Shadrack, M., N. Charles, G. Kamau, O. Gilbert, W. Phanice, K. Joyce and C. Dennis (2015). "Physical parameters of tropical wetlands in lake Victoria basin: a case study of Kigwal/Kimondi, Nyando and Nzoia Wetlands”, J Environ Anal Toxicol, 5(2).

Silva, M. D. and P. K. Silva, (1998). "Status, diversity and conservation of the mangrove forests of Sri Lanka", Journal of South Asian National History, 3(1): 79-102. 
Sinclair, A. R. E. and A. E. Byrom (2006). "Understanding ecosystem dynamics for conservation of biota",Journal of Animal Ecology, 75: 64-79.

Siwakoti, M., and S. Tiwari (2007). "Emerging needs of wetlands protection for the conservation of wild rice biodiversity in Nepal: a case study from Lumbini area", Science World, 5: 95-99

Survey Department (1988). National Atlas of Sri Lanka. Survey Department of Sri Lanka.

Trimen, H. (1893). "Handbook to the Flora of Ceylon”, Dulau and Company, London.

Wieski, K., H. Guo. B. C. Craft and S. T. Pennings (2010). "Ecosystem functions of tidal fresh, blackish and salt marshes on the Georgia Coast", Estuaries and Coasts, 33: 161-169.

William, M., and J. Gosselink (1986). Wetlands (Ed.). Van Nostrand Reinhold Company. N.Y.

Zeleny D. and M. Chytry (2007). "Pattern of $\alpha$ and $\beta$ diversity of vegetation in deep river valleys of Bohemia Massif". Proceedings of $16^{\text {th }}$ Workshop European Vegetation Survey, Italy, Rome. 


\section{Annex 1: Plant species present in the wetland marsh of the Ginthota}

\begin{tabular}{|c|c|c|}
\hline Type & Scientific name & Local name \\
\hline \multirow[b]{2}{*}{ Floating Vegetation } & Nymphaea pubescens & Kumudu (N) \\
\hline & $\begin{array}{l}\text { Nymphaea stellata } \\
\text { Lemna perpusilla }\end{array}$ & $\begin{array}{l}\text { Manel/Nil Manel (N) } \\
(\mathrm{N})\end{array}$ \\
\hline Submerged & Typha angustifolia & Hamba-pan/Yatidella (N) \\
\hline Vegetation & Ipomoea aquatic & Kankung (N) \\
\hline \multirow{4}{*}{$\begin{array}{l}\text { Emergent } \\
\text { Vegetation }\end{array}$} & Aponogeton crsipus & Kekatiya (N) \\
\hline & Hanguana malayana & Ketela $(\mathrm{N})$ \\
\hline & Commelina diffusa & Girapala $(\mathrm{N})$ \\
\hline & Hydrocera triflora & Diyakundalu (N) \\
\hline \multirow{14}{*}{ Herbs } & Fimbristylis miliacae & \\
\hline & Abutilon indicum & Kudumetta $(\mathrm{N})$ \\
\hline & Alocasia & Anoda(I) \\
\hline & macrorrhizos & Habarala (I) \\
\hline & Mimosa pudica & $\operatorname{Mimosa}$ pudica $(\mathrm{N})$ \\
\hline & Desmodium triflorum & Heenundupiyaliya (N) \\
\hline & Isachne globosa & Bata della $(\mathrm{N})$ \\
\hline & Dendrophothoe Spp & Pilila (N) \\
\hline & Leptochloa chinensis & Ashwawaligaya(N) \\
\hline & Cyperus rotundus & Kladuru(N) \\
\hline & Cyperus kyllingia & Mottu Thana(N) \\
\hline & Salvadora persica & Maliththan(N) \\
\hline & Eyphorbia & Wal Rubber(N) \\
\hline & heterophylla & Rathukimbulwenna(N) \\
\hline \multirow{16}{*}{ Shrubs } & Polygonum brabatum & \\
\hline & $\begin{array}{l}\text { Annona glabra } \\
\text { Melastoma }\end{array}$ & \\
\hline & malabathricum & Welattha(I) \\
\hline & Hydrocera triflora & Bovitiya $(\mathrm{N})$ \\
\hline & Dolichandrone & Diyakundalu(N) \\
\hline & spathacea & Diyadaga(N) \\
\hline & Symplocos & Wal-Bobu(N) \\
\hline & cochinchinensis & Rathmal(N) \\
\hline & Ixora hybrids & Belathana(N) \\
\hline & Cynodon dactylon & Kalanduru(N) \\
\hline & Cyperus rotandus & Podisinnomaran(I) \\
\hline & Eupatorium & Masan, Dabara(N) \\
\hline & odoratum & Etthora(N) \\
\hline & Ziziphus mauritiana & Gadapana(I) \\
\hline & Cassia alata & \\
\hline & Lantana camara & \\
\hline \multirow{5}{*}{ Trees } & Cerbera mangas & Gonkaduru(N) \\
\hline & Syzygium & Hindan(N) \\
\hline & caryophyllatum & $\operatorname{Attikka(N)}$ \\
\hline & Ficus racemosa & Wetakeyiya(N) \\
\hline & Pandanuss & Gurulla(N) \\
\hline
\end{tabular}




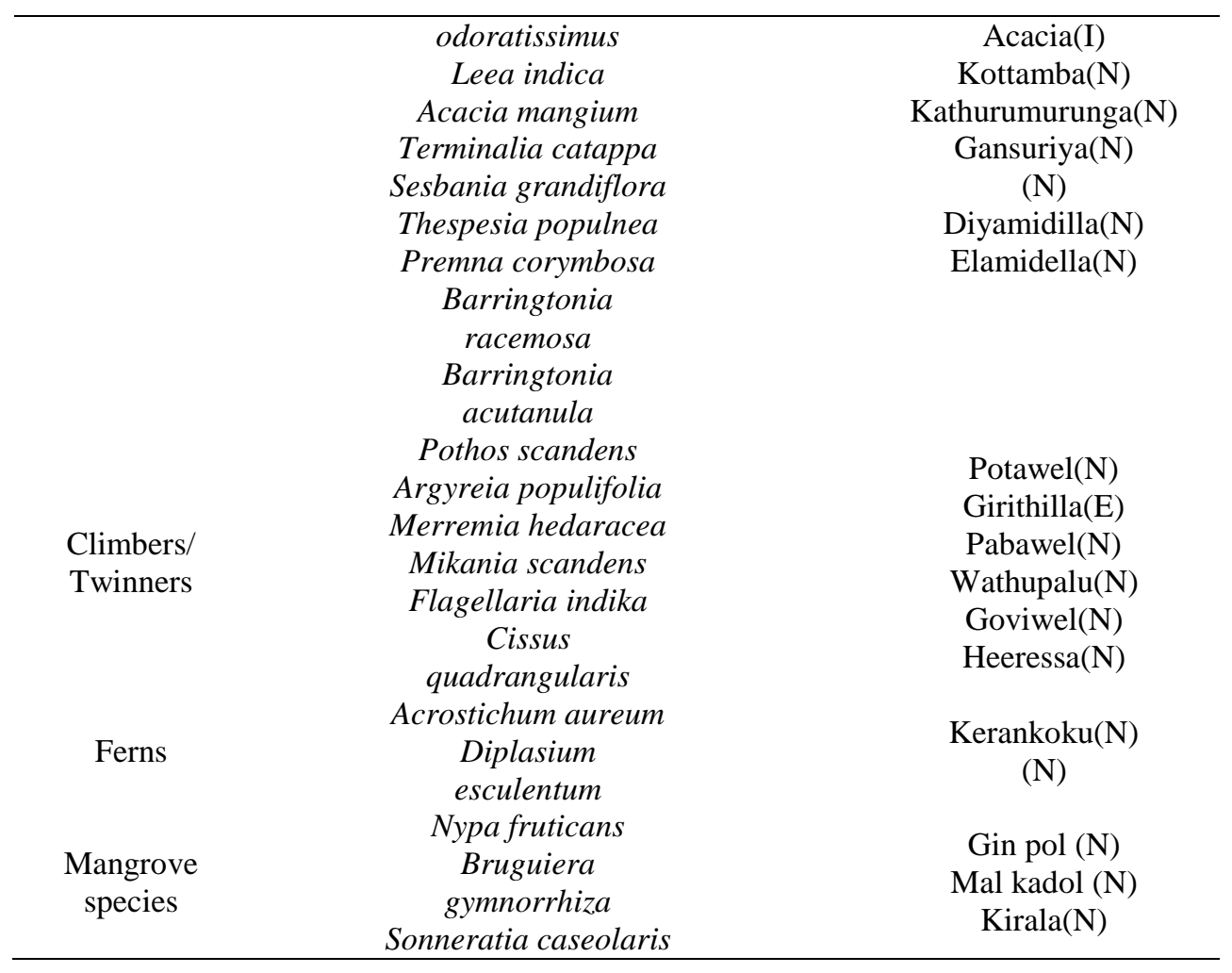

(N) - Native species

(I) - Introduce species

(E) - Endemic species 